\title{
Age and Growth of the Areolate Grouper Epinephelus areolatus from the Gulf of Suez
}

\author{
Ezzat Abd-Allah ${ }^{1}$, Azza El-Ganainy ${ }^{2}$, Alaa Osman ${ }^{1}$ \\ ${ }^{1}$ Zoology Department, Faculty of Science, Al-Azhar University, Assiut, Egypt \\ ${ }^{2}$ Fisheries Division, National Institute of Oceanography and Fisheries, Suez, Egypt
}

Email address:

ezzatmoh78@yahoo.com (E. Abd-Allah), azzaelgan@yahoo.com (A. El-Ganainy), agosman2@yahoo.com (A. Osman)

\section{To cite this article:}

Ezzat Abd-Allah, Azza El-Ganainy, Alaa Osman. Age and Growth of the Areolate Grouper Epinephelus areolatus from the Gulf of Suez. American Journal of Life Sciences. Special Issue: New Horizons in Basic and Applied Zoological Research.

Vol. 3, No. 6-1, 2015, pp. 7-12. doi: 10.11648/j.ajls.s.2015030601.12

\begin{abstract}
Age and growth of the associated coral reef grouper, Epinephelus areolatus, were estimated for samples collected from the artisanal fishery in the Gulf of Suez during November 2013 and October 2014. Otoliths of 597 specimens ranged in length from 11.2 to $50.5 \mathrm{~cm}$ were used in age determination. The otoliths showed alternating opaque (light) and translucent zones when seen by reflected light against a dark background, a translucent zone plus the opaque zone immediately around it formed an annulus. According to the otolith examination, the maximum life span of E areolatus was eight years with mean lengths of $16.9,24,29.9,35.7,39.7,43.4,46.6$ and $49.7 \mathrm{~cm}$ for the age groups from one to eight respectively. Individuals belong to age group two constituted the bulk of the catch with more than $60 \%$ of the population. The results showed that the $E$. areolatus is a relatively slow growing species and the values of the von Bertalanffy growth function was estimated as $\mathrm{K}=0.154, \mathrm{~L}_{\infty}=66.55 \mathrm{~cm}$ (LT) and $\mathrm{t}_{0}=-0.91$ years. The estimated growth performance index is 2.83 . The length weight relationship was estimated as $\mathrm{a}=0.0135$ and $\mathrm{b}=2.9947, \mathrm{r}^{2}=0.981$ indicating an isometric growth of the weight relative to the length.
\end{abstract}

Keywords: Age and Growth, Epinephelus areolatus, Gulf of Suez

\section{Introduction}

Groupers (Serranidae: Epinephelinae) are major targets of artisanal, recreational and commercial fisheries in the Red Sea. Groupers are being subjected to increasing fishing pressure for food, ornamental display and medical purposes globally $[1,2]$.

Groupers are widespread in the Red Sea from a few meters to even 200 meters depth and are famous for high commercial value. The members of Serranidae family which comprises a large number of species; at least 31 of which are found in the Red [3] are among the most commercially important fishes in the Red Sea. Worldwide, chronic overfishing has depleted populations of large predatory reef fishes and caused unexpected, top-down changes in coral reef ecosystems. Groupers are especially susceptible to overexploitation, because they aggregate to reproduce at specific locations and times. An understanding of the spatial dynamics of these fishes is critical for fisheries management and conservation [4].
The areolate grouper Epinephelus areolatus is a sea fish that inhabits coral reefs in the Indo-Pacific region, whitish to gray in color with rounded brownish spots. It is a very common species in the Red Sea. Biological studies on E. areolatus is very scarce, thus $[5,6]$ conducted some biological and fisheries studies on the Serranidae Epinephelus areolatus from the Red Sea. [7, 8] studied the reproductive biology of E. areolatus from the Arabian Gulf, while [9] investigated the reproductive biology and life history of the species from the central eastern coast of India. This study aims to investigate the age, growth and length weight relationship as a seed information for the population structure and management studies of Epinephelus areolatus in the Gulf of Suez

\section{Material and Methods}

The samples used in this study were collected monthly (during the period from November 2013 to October 2014 from the catches of the artisanal fishery operating in the Gulf of Suez and landed in the Attacka landing site. The total 
length of each sampled areolate grouper was measured to the nearest centimeter above and weighted to nearest $0.1 \mathrm{gm}$. All the fish collected, irrespective of sex, were grouped into size classes of $1.0 \mathrm{~cm}$ intervals according to the month of capture. The mean lengths and weights of each size class were also recorded.

Otoliths were removed from these fishes, for subsequent examination relevant to age determination. Before aging, otoliths were cleaned by $8 \% \mathrm{Hcl}$, and dried. The otoliths were cleared in a mixture of $50 \%$ alcohol and $50 \%$ glycerin and examined using a stereo microscope at a magnification of $40 \mathrm{X}$. Age was determined by interpreting growth rings on the otoliths. The length weight relationship was applied as $\mathrm{W}=\mathrm{a} \mathrm{L}^{\mathrm{b}}$ where $\mathrm{W}$ is the total weight, $\mathrm{L}$ is the total length, and $\mathrm{a}, \mathrm{b}$ are constants.

Growth was described by the von Bertalanffy growth model [10]. The length at age data were used for the estimation of the parameters of the von Bertalanffy growth model $\left(\mathrm{L}_{\infty}, \mathrm{K}\right.$ and $\left.\mathrm{t}_{\mathrm{o}}\right)$ by applying three methods [11][12][13]-[14]. The empirical equation of [15] was used to estimate the hypothetical age $\left(\mathrm{t}_{\mathrm{o}}\right)$ of fish, which would have at zero length. The growth performance index Q' was estimated to compare growth parameters obtained in the present work with those reported by other authors, it was obtained from the equation of [16].

$$
\varnothing=\log K+2 \log \mathrm{L} \infty
$$

\section{Results and Discussion}

\subsection{Length-weight Relationship}

A total of 597 specimens of Epinephelus areolatus (76 males, 518 females and 3 unsexed) were used for the calculations of the length weight relationship. Samples of male $E$ areolatus lengths ranged from 18.7 to $48.6 \mathrm{~cm}$ with average of $28.14 \mathrm{~cm}(\mathrm{SD}=6.09)$, corresponding to weights of 83.1 to 1610 and $345.87 \mathrm{~g}(\mathrm{SD}= \pm 284.5)$ for minimum, maximum and average lengths respectively. On the other hand, samples of female lengths ranged from minimum length $11.2 \mathrm{~cm}(17.1 \mathrm{~g})$ to maximum length $50.5 \mathrm{~cm}(1944.3$ g) with an average of $25.79 \mathrm{~cm}(256.65 \mathrm{~g}),(\mathrm{SD}= \pm 5.06$ and $\mathrm{SD}= \pm 194.28$ for length and weight respectively) (Table 1).

Table 1. Descriptive statistics of mean for Epinephelus areolatus from Gulf of Suez during the period from November, 2013 to October, 2014.

\begin{tabular}{|c|c|c|c|c|c|c|}
\hline \multirow{2}{*}{$\begin{array}{l}\text { Descriptive } \\
\text { statistics }\end{array}$} & \multicolumn{2}{|l|}{ Male } & \multicolumn{2}{|l|}{ Female } & \multicolumn{2}{|c|}{ Combined sex } \\
\hline & Length & Weight & Length & Weight & Length & Weight \\
\hline Fish No. & 76 & & 518 & & 597 & \\
\hline Minimum & 18.7 & 83.1 & 11.2 & 17.1 & 11.2 & 17.1 \\
\hline Mean & 28.14 & 345.67 & 25.79 & 256.65 & 26.05 & 267.03 \\
\hline SD & 6.092 & 284.505 & 5.067 & 194.281 & 5.259 & 209.176 \\
\hline SE & 0.708 & 33.073 & 0.222 & 8.520 & 0.215 & 8.561 \\
\hline
\end{tabular}

*SD, Standard deviation and *SE, Standard error.

The length- weight relationships were calculated for each sex and for the combined sexes for the total weight and also for the gutted weight and the estimated $b$ constant indicated an isometric growth of the weight relative to the length. The relationships are expressed in the following equations:

The total length- total weight represented by power equations (Fig 1):

$$
\mathrm{W}=0.0112 \mathrm{~L} 3.0509 \text { for males }(\text { No. }=74 \text { and } \mathrm{r} 2=0.986) \text {. }
$$$$
(\mathrm{SEa}=0.145, \mathrm{SEb}=0.044, \mathrm{CIb}=2.964-3.138)
$$

$\mathrm{W}=0.0139 \mathrm{~L} 2.9842$ for females (No. $=518$ and $\mathrm{r} 2=0.979)$.

$(\mathrm{SEa}=0.061, \mathrm{SEb}=0.0 .19, \mathrm{CIb}=2.947-3.022)$

$\mathrm{W}=0.0135 \mathrm{~L} 2.9947$ for all samples (No. $=597$ and $\mathrm{r} 2=$ 0.981).

$(\mathrm{SEa}=0.056, \mathrm{SEb}=0.017, \mathrm{CIb}=2.958-3.026)$

Total length- Gutted weight represented by power equations (Fig 2).

$$
\begin{gathered}
\mathrm{Wg}=0.0101 \mathrm{~L}^{3.0686} \text { for males }\left(\text { No. }=74 \text { and } \mathrm{r}^{2}=0.988\right) . \\
\left(\mathrm{SE}_{\mathrm{a}}=0.137, \mathrm{SE}_{\mathrm{b}}=0.041, \mathrm{CI}_{\mathrm{b}}=2.985-3.151\right) \\
\mathrm{Wg}=0.0123 \mathrm{~L}^{3.0085} \text { for females }\left(\mathrm{No} .=518 \text { and } \mathrm{r}^{2}=0.982\right) . \\
\left(\mathrm{SE}_{\mathrm{a}}=0.061, \mathrm{SE}_{\mathrm{b}}=0.019, \mathrm{CI}_{\mathrm{b}}=2.971-3.045\right) \\
\mathrm{Wg}=0.0119 \mathrm{~L}^{3.0171} \text { for combined sexes }\left(\text { No. }=597 \text { and } \mathrm{r}^{2}=\right. \\
0.983) . \\
\left(\mathrm{SE}_{\mathrm{a}}=0.056, \mathrm{SE}_{\mathrm{b}}=0.017, \mathrm{CI}_{\mathrm{b}}=2.983-3.050\right)
\end{gathered}
$$

Hassan [5] calculated the length weight relationship for combined sexes of Epinephelus areolatus from the Red Sea as $\mathrm{W}=0.016449 * \mathrm{~L}^{2.9359}$. Sujatha [9] estimated the relationship for E. areolatus from the central eastern coast of India as $\mathrm{W}=0.00133 * \mathrm{~L}^{2.946}$. These results are in close agreement with the present study. 

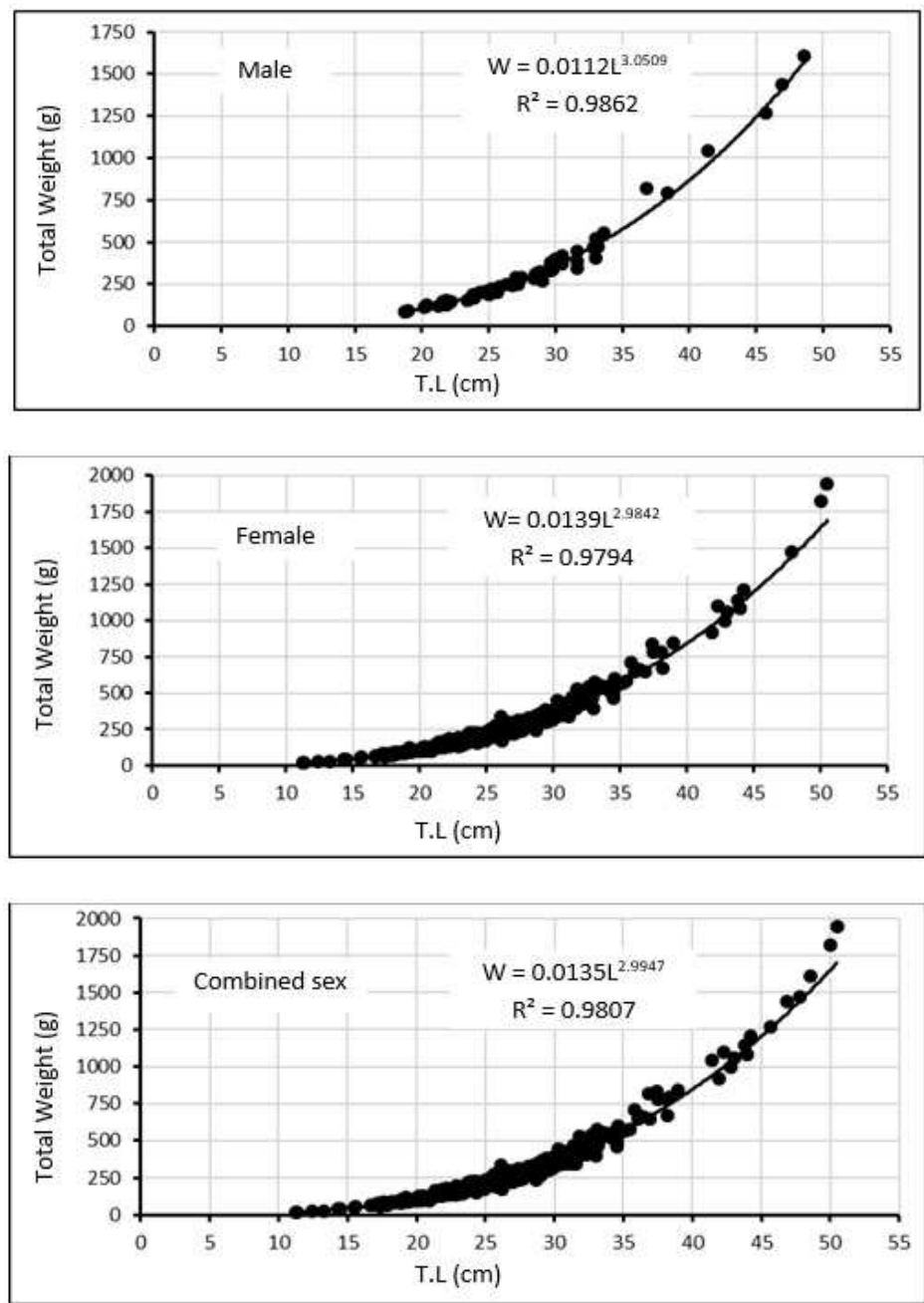

Fig. 1. Total length-total weight relationship for males, females and combined sexes of E areolatus from the Gulf of Suez during the period of study (20132014).
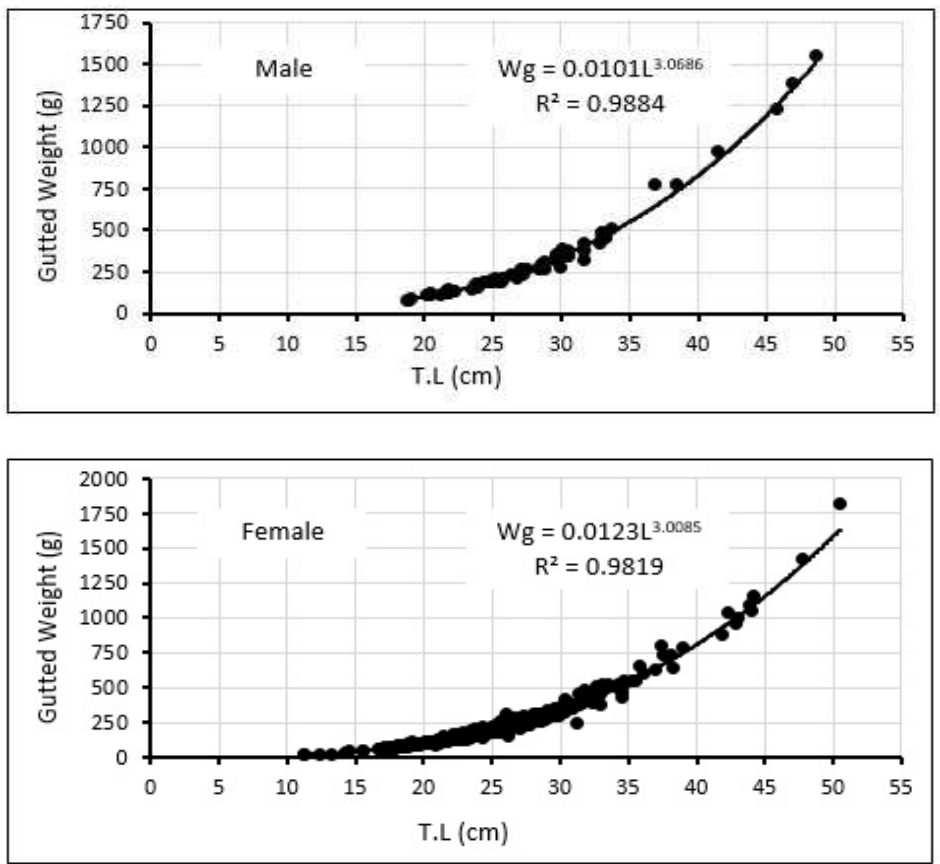


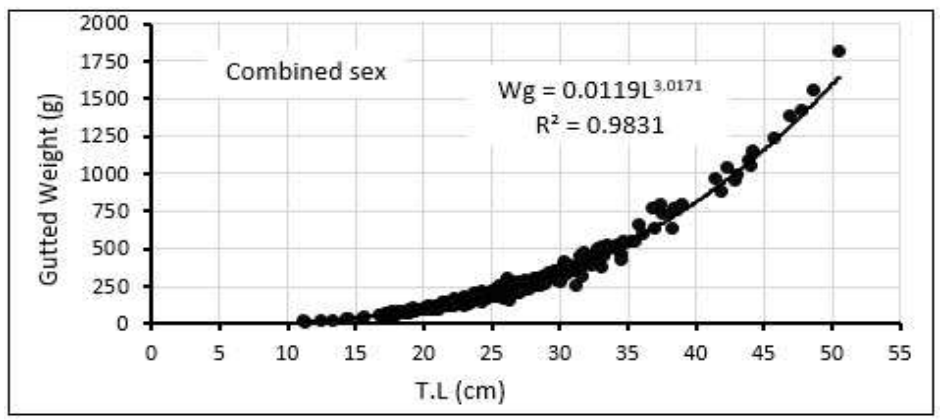

Fig. 2. Total length-gutted weight relationship for males, females and combined sexes of E areolatus from the Gulf of Suez during the period of study (20132014).

\subsection{Age Determination}

The otoliths of Epinephelus areolatus are laterally compressed, oval structures which has a concave and a convex surface, the latter having a ridge down the center. The posterior edge is blunt and rounded while the margins are irregularly indented. The focus is surrounded by a wide opaque zone, the core. When seen by reflected light against a dark background, the otolith show alternating opaque (light) and translucent zones. Under transmitted light, the opaque zone becomes dark while the translucent zone becomes light. A translucent zone plus the opaque zone immediately around it are together defined as "growth ring" or "annulus". The beginning of the second ring is translucent and separated from the former opaque zone, Fig. (3).

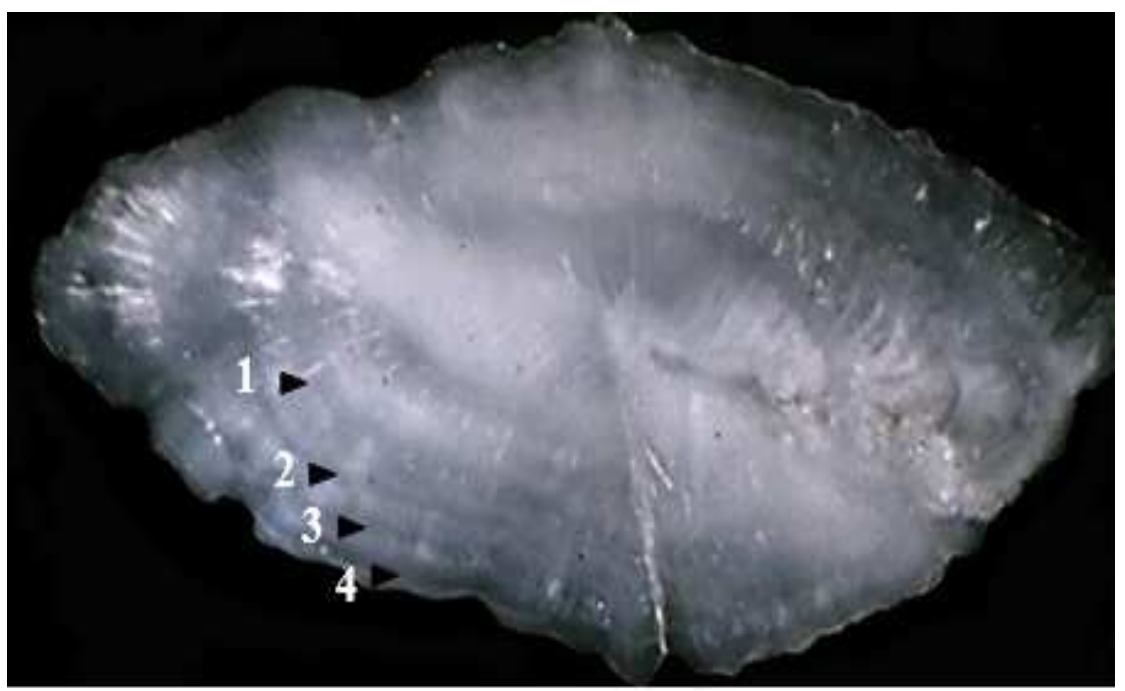

Fig. 3. Otolith of areolate grouper Epinephelus areolatus collected from the Gulf of Suez (35.2 cm total length, 4 years old).

Table 2. Mean lengths and increment at each age group of Epinephelus areolatus estimated by otolith reading.

\begin{tabular}{|c|c|c|c|c|c|c|}
\hline \multirow{2}{*}{ Age group } & \multirow{2}{*}{ No. ofFish } & \multicolumn{2}{|c|}{ Range of Length (cm) } & \multirow{2}{*}{ Average Length } & \multirow{2}{*}{ Increment (cm) } & \multirow{2}{*}{$\pm \mathrm{SD}$} \\
\hline & & Min. & Max. & & & \\
\hline $\mathrm{I}$ & 34 & 11.2 & 19 & 17.0 & 16.96 & 2.19 \\
\hline II & 376 & 18.3 & 27.6 & 24.0 & 7.064 & 2.22 \\
\hline III & 153 & 27.1 & 34.5 & 30.0 & 5.96 & 1.70 \\
\hline IV & 14 & 34.2 & 37.5 & 35.7 & 5.74 & 1.14 \\
\hline V & 8 & 38.1 & 42.3 & 39.7 & 3.95 & 1.85 \\
\hline VI & 4 & 42.8 & 44 & 43.4 & 3.7 & 0.59 \\
\hline VII & 5 & 44.2 & 48.4 & 46.6 & 3.2 & 1.68 \\
\hline VIII & 3 & 48.6 & 50.5 & 49.7 & 3.1 & 0.98 \\
\hline
\end{tabular}

The otoliths of 597 specimens were used in age determination of Epinephelus areolatus. According to the otolith examination, the maximum life span of $E$ areolatus was eight years with mean lengths at age of 16.9, 24, 29.9, 35.7, 39.7, 43.4, 46.6 and 49.7 for the age groups from one to eight respectively (Table 2). 


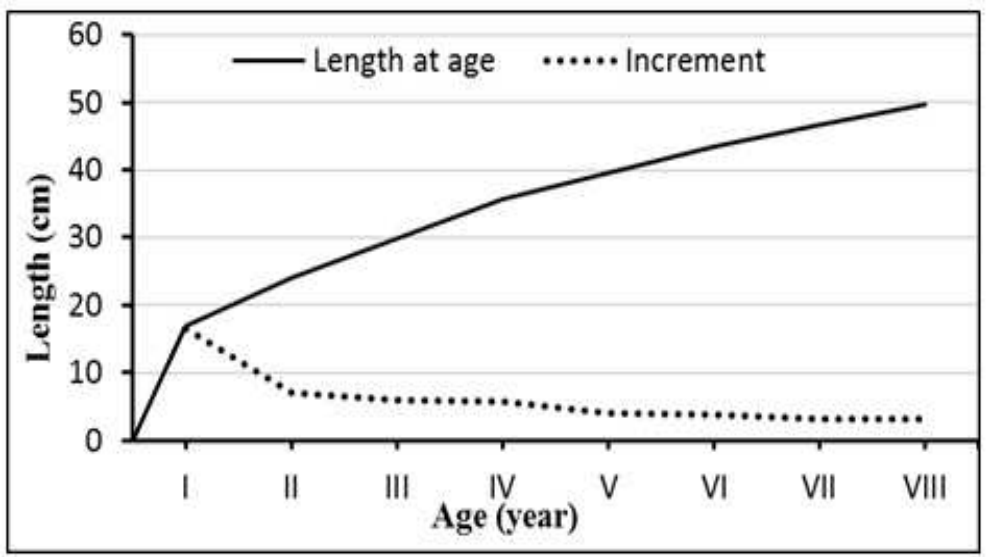

Fig. 4. Growth in length and increment of Epinephelus areolatus from the Gulf of Suez.

\subsection{Growth in Length and Weight}

The mean calculated length at age of Epinephelus areolatus were used for the estimation of the parameters of the von Bertalanffy growth model $\left(\mathrm{L}_{\infty}, \mathrm{K}\right.$ and $\left.\mathrm{t}_{\mathrm{o}}\right)$ by applying three methods [11][12][13]-[14] (Table 3).

Table 3. The parameters of the von Bertalanffy growth model of Epinephelus areolatus.

\begin{tabular}{llll}
\hline Constant & Ford-Walford & Gulland and Holt & Chapman \\
\hline $\mathrm{L}_{\infty}$ & 66.55 & 66.65 & 66.55 \\
$\mathrm{~K}$ & 0.154 & 0.153 & 0.133 \\
$\mathrm{~T}_{\mathrm{o}}$ & -0.91 & -0.92 & -1.35 \\
\hline
\end{tabular}

The mean estimated lengths at age indicated rapid growth in the 1st year of life then the rate of growth slows down. The estimated growth parameters showed that the areolate grouper is a relatively long lived species with slow growth rate and age group two was the most predominant in the catch represented by more than $60.0 \%$ of the individuals. Hassan [5] recorded the values of the von Bertalanffy growth function as $\mathrm{K}=0.13, \mathrm{~L} \infty=78.92 \mathrm{~cm}$ (LT) and $\mathrm{t} 0=-1.102$ years. The result of the growth coefficient $\mathrm{K}$ is comparable to the result of the present study while the result of $L \infty$ is higher than ours which may be attributed to the higher recorded maximum length from the Red Sea than that from the Gulf of Suez.
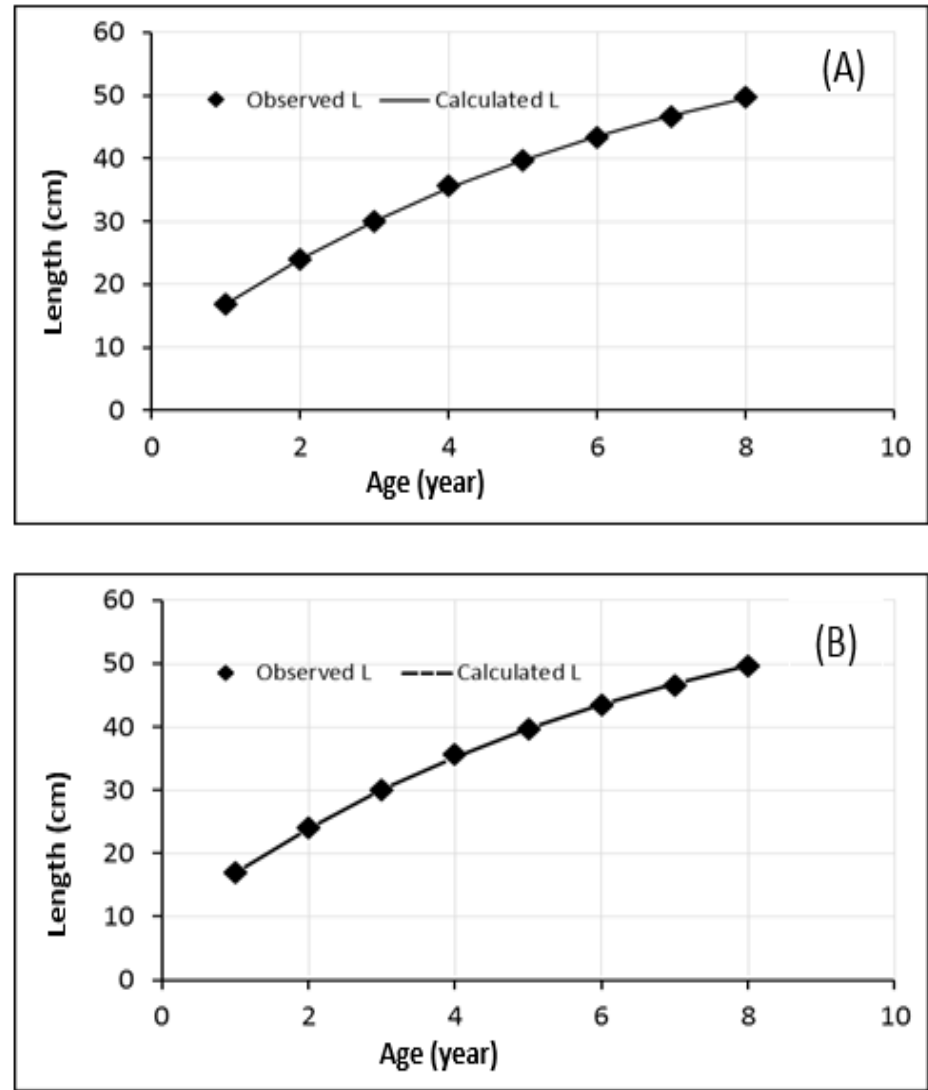


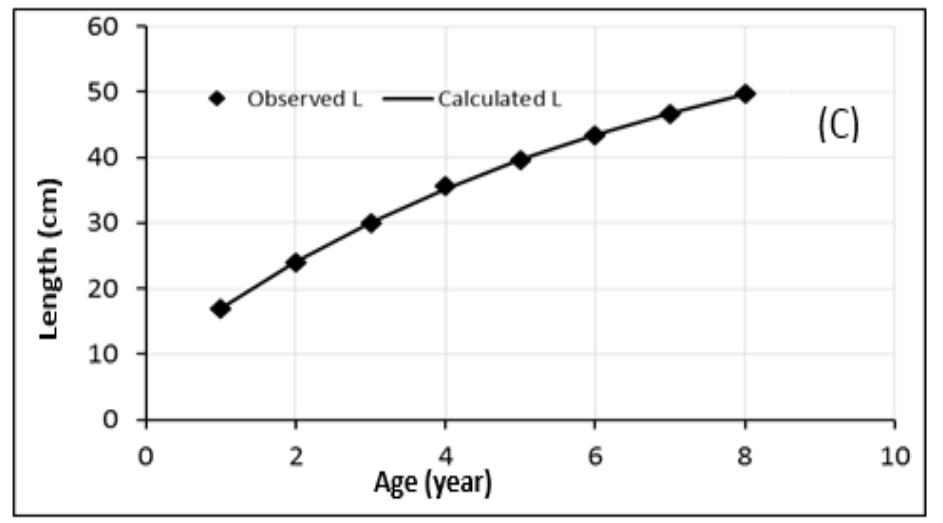

Fig. 5. Growth in length of Epinephelus areolatus from the Gulf of Suez by (A) Ford-Walford fitting method, (B) Gulland and Holt fitting method and (C) Chapman fitting method.

\subsection{Growth Performance Index ( $\varphi)$}

The results showed that the growth performance $(\varphi)$ of $E$. areolatus is $2.83,2.77$ and 2.83 according to [13]-[14][12][11] respectively. These results are in accordance with that estimated from [5] growth parameters $(\varphi=2.9)$.

\section{References}

[1] D. Pauly, V. Christensen, S. Guénette, T. Pitcher, U. R. Sumaila, C. Walters, R. Watson and D. Zeller, "Toward sustainability in world fisheries," Nature. Vol .418, pp.689695, 2002.

[2] A. C. J. Vincent and Y. J. Sadovy, "Reproductive ecology in the conservation and management of fishes." Pp.209-245, 1998. In T. M. Caro, ed. Behavioural Ecology and Conservation Biology. Oxford University Press, New York.

[3] J. E. Randall, "Red Sea reef fishes," IMMEL Publications, London. 192 pp. 1983.

[4] R. M. Starr, E. Sala, E. Ballesteros and M. Zabala, "Spatial dynamics of the Nassau grouper Epinephelus striatus in a Caribbean atoll," Marine Ecology Progress Series. Vol. 343, pp.239-249, 2007.

[5] A. A. Hassan, "Biology and fishery studies on the Serranidae Epinephelus areolatus from the Red Sea," Ph.D. Thesis, Ain Shams University, Egypt, 1988.

[6] H. H. Mahmoud, "Gonadal Maturation and Histological Observations of Epinephelus areolatus and Lethrinus nebulosus in Halaieb/Shalatien Area, Red Sea, Egypt," Global Veterinaria, vol. 3(5), pp.414-423,2009.

[7] H. F. Alkahem, Z. Ahmad and A. A. A. Al-Dhahi, "Studies on age and growth of Epinephelus chlorostigma and Epinephelus areolatus from Arabian Gulf," Agriculture Research Journal. Suez Canal University. Vol. 3(1), pp.27-31, 2004.
[8] A. Zubair, H. A. Al-Kahem and A. A. Amir, "Fecundity, Sex Ratio and Gonado-somatic Index of Epinephelus Chlorostigma and Epinephelus Areolatus Sampled from Arabian Gulf," Animal Biology Journal. Vol. 2(3), pp.87-96, 2011.

[9] k. Sujatha, V. L. S. kantimahanti and. V. A. D. Iswarya, "Species diversity and some aspects of reproductive biology and life history of groupers (Pisces: Serranidae: Epinephelinae) off the central eastern coast of India," Marine Biology Research. Vol. 11(1), pp.18-33, 2015.

[10] W. E. Ricker, "Computation and interpretation of biological statistics of fish population," Bull. Fish. Res. Bd. Can., No. (191) 382pp.1975.

[11] D. G. Chapman, "Statistical problemsh in dynamics of exploited fisheries population," Proc. 4 . Berkeley Symp. Math. Statist. Probl., vol. 4, pp.153-168, 1960.

[12] J. A. Gulland and S. L. Holt, "Estimation of growth parameter for data at unequal time intervals," J. Cons. Perm. Int. Explor. Mer, vol. 25(1), pp47-49, 1959.

[13] E. Ford, "An account of the herring investigation conductive at Plymouth during the years from 1929-1933," J. Mar. Bio. Asse. U. K. vol. 19, pp.305-384, 1933.

[14] L. A. Walford, "A new graphic method of describing the growth of animals," Biol. Bull. vol. 90(2), pp.141-147, 1946.

[15] D. Pauly, "Theory and management of tropical multispecies stocks: a review with emphasis on the Southeast Asian demersal fisheries," ICLARM Review Studies 1: 35pp. 1979.

[16] J. Moreau, C. Bambino and D. Pauly, "Indices of overall growth performance of 100 tilapia (Cichlidae) populations," pp.201-206, 1986. In: J.L. Maclean, L.B. Dizon \& L.V. Hosillos (eds.) The First Asian Fisheries Forumn 727 p. Asian Fisheries Society, Manila, Philippines. 